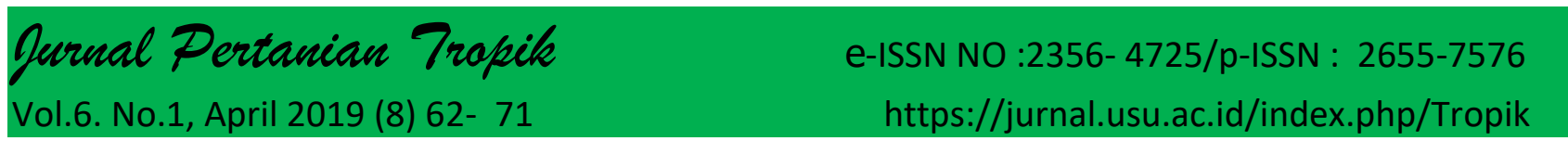

\title{
Evaluasi Kemampuan Beberapa Jenis Tanaman Sebagai Fitoremediasi Logam Berat Kadmium
}

\section{Evaluation Ability of Several Plant as Phytoremediation of Cadmium Heavy Metal}

\author{
Yustina Sri Sulastri ${ }^{1 *}$, Edison Purba ${ }^{2}$, \& Koko Tampubolon ${ }^{1}$ \\ ${ }^{1}$ Program Doktor Ilmu Pertanian, Fakultas Pertanian, Universitas Sumatera Utara, Padang Bulan, \\ Medan 20155, Indonesia. \\ ${ }^{2}$ Program Studi Agroteknologi, Fakultas Pertanian, Universitas Sumatera Utara, Padang Bulan, \\ Medan 20155, Indonesia. \\ *Corresponding author : yustina041067@gmail.com
}

\begin{abstract}
Cadmium iis very dangerous when enters the human physiological system. This research was aimed to evaluation ability of several plants as phytoremediation of cadmium heavy metal. This research was conducted in experimental field, Faculty of Agriculture, Universitas Sumatera Utara on March to May 2018. This research used non factorial randomized block design (RBD) with three replications. Treatment of Vetiveria zizanioides (T1), Cymbopogon nardus (T2), Curcuma xantorrhiza (T3), Cymbopogon citratus (T4), Pogostemon cablin (T5), and Alpinia galanga (T6) were given $3 \mathrm{CdSO}_{4} .8 \mathrm{H}_{2} \mathrm{O} 100 \mathrm{ppm}$. The parameters include soil $\mathrm{pH}$, root length (cm), fresh and dry weight of roots $(\mathrm{g})$, fresh and dry weight of shoots $(\mathrm{g})$, and total Cd uptake (ppm). The results showed that Cymbopogon nardus plant (T2) had ability to accumulate the highest of total Cd heavy metals amount $20.29 \mathrm{ppm}$, fresh weight of root $(111.73 \%)$, dry weight of root $(105.83 \%)$, root length $(75.33 \mathrm{~cm})$, fresh weight of shoot (60.89\%), and dry weight of shoot (93.14\%) compared to Cd unexposed. Scented lemongrass plants can be used as phytoremediation plants for heavy metal cadmium which has mechanism of phytoextraction or phytoaccumulation.
\end{abstract}

Keywords: Cadmium, Heavy Metals, Phytoremediation, Plants.

\begin{abstract}
ABSTRAK
Kadmium merupakan logam yang sangat berbahay bila masuk kedalam sistem fisiologis tubuh manusia. Penelitian ini bertujuan untuk mengevaluasi kemampuan beberapa jenis tanaman sebagai fitoremediasi logam berat kadmium. Penelitian ini dilaksanakan di Lahan Percobaan Fakultas Pertanian Universitas Sumatera Utara pada Maret sampai dengan Mei 2018. Penelitian ini menggunakan Rancangan Acak Kelompok (RAK) non faktorial dengan tiga ulangan. Perlakuan akar wangi $\left(\mathrm{T}_{1}\right)$, serai wangi $\left(\mathrm{T}_{2}\right)$, temulawak $\left(\mathrm{T}_{3}\right)$, serai $\left(\mathrm{T}_{4}\right)$, nilam $\left(\mathrm{T}_{5}\right)$, dan lengkuas $\left(\mathrm{T}_{6}\right)$ diberikan $3 \mathrm{CdSO}_{4} .8 \mathrm{H}_{2} \mathrm{O} 100 \mathrm{ppm}$. Parameter penelitian ini antara lain $\mathrm{pH}$ tanah akhir, panjang akar $(\mathrm{cm})$, berat basah dan kering akar $(\mathrm{g})$, berat basah dan kering tajuk (g), serta serapan Cd total (ppm). Hasil penelitian menunjukkan bahwa tanaman serai wangi memiliki kemampuan mengakumulasi logam berat $\mathrm{Cd}$ total tertinggi sebesar 20,29 ppm, memiliki berat basah akar (111,73\%), berat kering akar $(105,83 \%)$, panjang akar $(75,33 \mathrm{~cm})$, berat basah tajuk $(60,89 \%)$, dan berat kering tajuk $(93,14 \%)$ dibandingkan tanpa terpapar $\mathrm{Cd}$. Tanaman serai wangi dapat dijadikan sebagai tanaman fitoremediasi logam berat kadmium yang memiliki mekanisme fitoekstraksi atau fitoakumulasi.
\end{abstract}

Kata kunci : Fitoremediasi, Kadmium, Logam Berat, Tanaman. 


\section{PENDAHULUAN}

Tanah-tanah pertanian yang terkontaminasi logam berat beracun merupakan masalah lingkungan yang besar yang dapat mempengaruhi pertumbuhan tanaman. Peningkatan kontaminasi logam berat pada tanah di atas 30 hingga 40 tahun mendatang akan menyebabkan stress lingkungan yang akan membatasi penggunaan lahan (McGrath et al. 2002). Logam berat adalah unsur logam dengan berat molekul tinggi, berat jenisnya lebih dari lima $\mathrm{g} / \mathrm{cm}^{3}$ (Clemens et al. 2002).

Pemasok logam berat dalam tanah pertanian antara lain bahan agrokimia (pupuk dan pestisida), asap kendaraan bermotor, bahan bakar minyak, pupuk organik, buangan limbah rumah tangga, industri, dan pertambangan. Selain itu sumber logam berat dalam tanah berasal dari bahan induk pembentuk tanah itu sendiri, seperti Cd banyak terdapat pada batuan sedimen schales $(0,22$ ppm) (Zoidis et al. 2010).

Kadmium $(\mathrm{Cd})$, timbal $(\mathrm{Pb})$, kuprum $(\mathrm{Cu})$, dan zinkum $(\mathrm{Zn})$ merupakan kontaminan logam berat utama tanah pertanian dan dikonsentrasi tinggi dapat memberikan efek toksik pada tanaman. Menurut Nopriani, (2011) menyatakan bahwa diantara semua unsur logam berat, $\mathrm{Hg}$ menduduki urutan pertama dalam hal sifat toksiksitasnya, dibandingkan dengan logam berat lainnya, kemudian diikuti oleh logam berat antara lain $\mathrm{Cd}, \mathrm{Ag}, \mathrm{Ni}, \mathrm{Pb}, \mathrm{As}, \mathrm{Cr}, \mathrm{Sn}, \mathrm{Zn}$. Diantara semua logam berat, kadmium $(\mathrm{Cd})$ merupakan logam yang lebih mudah diakumulasi oleh tanaman dibandingkan dengan logam berat lainnya.

Penyerapan $\mathrm{Cd}$ dari tanah oleh tanaman dipengaruhi oleh total pemasukan $\mathrm{Cd}$ dalam tanah, $\mathrm{pH}$ tanah, kandungan $\mathrm{Zn}$, jenis tanaman dan kultivar. Penyerapan $\mathrm{Cd}$ akan tinggi pada $\mathrm{pH}$ rendah dan menurun pada $\mathrm{pH}$ tinggi. Kandungan seng $(\mathrm{Zn})$ yang tinggi dapat mengurangi penyerapan $\mathrm{Cd}$. Jika $\mathrm{Cd}$ telah memasuki rantai makanan, maka pada akhirnya akan terakumulasi pada konsumen tingkat tinggi yaitu hewan dan manusia. Kadmium sangat membahayakan kesehatan karena pengaruh racun akut dari unsur tersebut sangat buruk (Lin and Aarts, 2012).

Alternatif yang dapat digunakan untuk menghindari tercemarnya tanah dari logam berat kadmium, salah satunya adalah fitoremediasi. Hardyanti dan Rahayu, (2007) mengatakan bahwa fitoremediasi merupakan upaya penggunaan tanaman dan bagianbagiannya untuk dekontaminasi limbah dan masalah-masalah pencemaran lingkungan baik secara ex-situ menggunakan kolam buatan atau reaktor maupun in-situ (langsung di lapangan) pada tanah atau daerah yang terkontaminasi limbah.

Fitoremediasi dapat dibagi menjadi fitoekstraksi, rizofiltrasi, fitodegradasi, fitostabilisasi, fitovolatilisasi. Fitoekstraksi mencakup penyerapan kontaminan (logam berat) melalui akar kemudian ditranslokasi atau diakumulasi ke bagian tumbuhan seperti akar, daun atau batang. Rizofiltrasi adalah pemanfaatan kemampuan akar tumbuhan untuk menyerap, mengendapkan, dan mengakumulasi logam dari aliran limbah. Fitodegradasi adalah metabolisme kontaminan di dalam jaringan tumbuhan, misalnya oleh enzim dehalogenase dan oksigenase. Fitostabilisasi adalah suatu fenomena diproduksinya senyawa kimia tertentu untuk mengimobilisasi kontaminan di daerah rizosfer. Fitovolatilisasi terjadi ketika tumbuhan menyerap kontaminan dan melepasnya ke udara lewat daun; dapat pula senyawa kontaminan mengalami degradasi sebelum dilepas lewat daun (Tsao, 2003).

Peneltian fitoremediasi logam berat kadmium sudah sering dilakukan. Menurut Zhang et al., (2014) menyatakan bahwa tanaman akar wangi dapat mengakumulasi $\mathrm{Cd}$ pada akar dan tajuk tanaman berturut-turut sebesar $167-396 \mathrm{mg} / \mathrm{kg}$ dan 0,13-9,0 mg/kg. Dengan demikian tanaman akar wangi lebih tinggi mengakumulasi logam berat kadmium di akar dibandingkan di tajuk. Menurut Hapsari dan Lestari, (2017) menyatakan bahwa tanaman biduri memiliki kemampuan menyerap logam berat $\mathrm{Cd}$ pada akar sebesar 1,26 ppm dan pada bagian tajuk sebesar 1,01 ppm. 
Dengan demikian diperlukan penelitian mengenai fitoremediasi logam berat kadmium menggunakan beberapa spesies tanaman agar diperoleh informasi awal dalam mengendalikan logam berat pada tanah pertanian yang terkonaminasi. Tujuan penelitian ini adalah untuk mengevaluasi kemampuan beberapa jenis tanaman sebagai fitoremediasi logam berat kadmium.

\section{BAHAN DAN METODE}

Penelitian ini dilaksanakan di lahan percobaan Fakultas Pertanian Universitas Sumatera Utara. Analisis $\mathrm{pH}$ tanah dilakukan di PT Socfin Indonesia. Analisis serapan Cd tanaman dilakukan di Laboratorium Penelitian, Fakultas Farmasi, Universitas Sumatera Utara. Penelitian ini dilaksanakan dari bulan Maret sampai dengan Mei 2018.

Penelitian ini menggunakan Rancangan Acak Kelompok Non Faktorial dengan perlakuan enam spesies tanaman pada dua kondisi tanah yang berbeda (tanah yang tidak terpapar dan terpapar logam berat kadmium 100 ppm). Setiap perlakuan dibuat 3 ulangan.

Persiapan Media Tanam dan Bahan Tanam Sebelum tanam, disiapkan dan ditimbang tanah $10 \mathrm{~g}$ untuk pengukuran $\mathrm{pH}$ tanah awal. Kemudian dianalisis kandungan logam berat kadmium dalam tanah tersebut. Tanah yang akan digunakan dikeringanginkan kemudian dimasukkan ke polybag ukuran 40 $\mathrm{cm}$ x $20 \mathrm{~cm}$ (ukuran $5 \mathrm{~kg}$ ).

Enam jenis tanaman yakni akar wangi $\left(T_{1}\right)$, serai wangi $\left(T_{2}\right)$, temulawak $\left(T_{3}\right)$, serai $\left(\mathrm{T}_{4}\right)$, nilam $\left(\mathrm{T}_{5}\right)$, dan lengkuas $\left(\mathrm{T}_{6}\right)$ dapat dilihat Gambar 1. Tanaman akar wangi $\left(\mathrm{T}_{1}\right)$ diambil dari indukan yang sudah berumur 3 bulan, dilakukan dengan pemotongan dengan ukuran tinggi $20 \mathrm{~cm}$ dan panjang akar $8 \mathrm{~cm}$ (Chen et al. 2004). Tanaman nilam ( $\left.\mathrm{T}_{5}\right)$ diperoleh dari bahan stek batang yang diambil dari tanaman induk yang sudah berumur 4 bulan, ukuran stek terdiri dari 3 ruas dan panjangnya $15 \mathrm{~cm}$ serta daun dipangkas lebih dahulu dengan menyisakan 2-4 helai daun muda. Tanaman temulawak $\left(\mathrm{T}_{3}\right)$ diambil dari rimpangnya dengan bobot sekitar $20 \mathrm{~g}$ (A'yun et al. 2015). Tanaman lengkuas $\left(\mathrm{T}_{6}\right)$ diambil dari rimpang dengan bobot sekitar $50 \mathrm{~g}$ berisi 2-3 tunas. Tanaman serai wangi $\left(\mathrm{T}_{2}\right)$ dan serai $\left(\mathrm{T}_{4}\right)$ yang digunakan dari bahan stek yang dipotong daunnya hingga sekitar 3- $5 \mathrm{~cm}$ dari pelepah daun, demikian pula dengan akar, dikurangi dengan pemotongan hingga menyisakan sekitar 2,5 cm dibawah leher akar (Sumiartha et al. 2012).

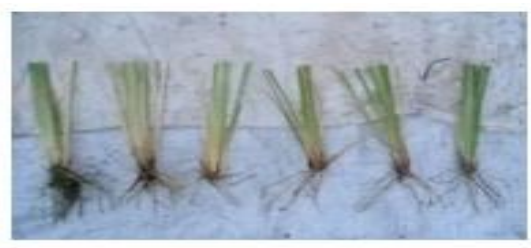

$T_{1}$

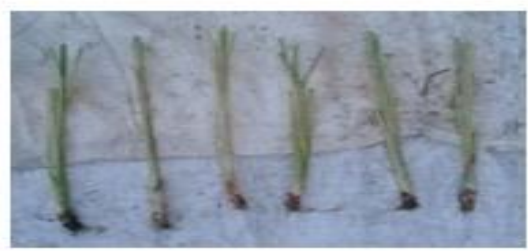

$\mathrm{T}_{4}$

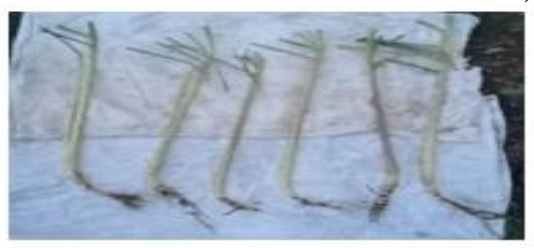

$\mathrm{T}_{2}$

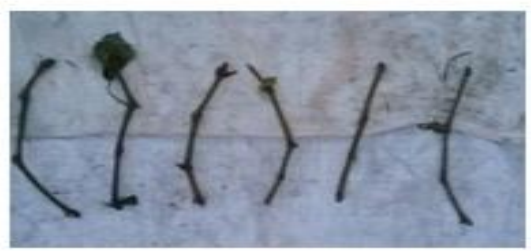

$\mathrm{T}_{5}$

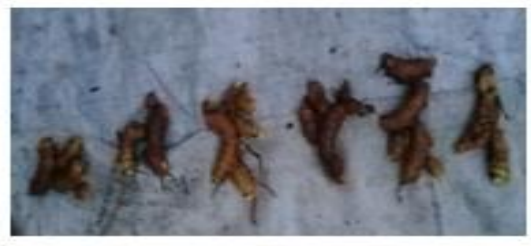

$T_{3}$



$T_{6}$

Gambar 1. Persiapan 6 jenis bahan tanaman. $\mathrm{T}_{1}$ (akar wangi), $\mathrm{T}_{2}$ (serai wangi), $\mathrm{T}_{3}$ (temulawak), $\mathrm{T}_{4}$ (serai), $\mathrm{T}_{5}$ (nilam), dan $\mathrm{T}_{6}$ (lengkuas). 
Aplikasi dan Analisi Logam Berat Kadmium

Disiapkan dan ditimbang logam berat kadmium $3 \mathrm{CdSO}_{4} .8 \mathrm{H}_{2} \mathrm{O}$ (bentuk bubuk) sebesar 0,5 g. Aplikasi dilakukan pada 6 minggu setelah tanam (MST).

Aplikasi dilakukan dengan cara dibenamkan di sekeliling perakaran tanaman. Analisis serapan logam berat di tanaman memiliki prinsip kerjan yaitu destruksi kering. Tanaman (akar dan tajuk) ditimbang ( $\pm 3 \mathrm{~g}$ ) kemudian dipotong-potong halus selanjutnya dimasukkan ke dalam wadah krusibel bertutup ukuran $50 \mathrm{ml}$. Krusibel tersebut selanjutnya dimasukkan ke dalam tanur untuk proses pengabuan. Pengabuan berlangsung dengan tahapan sebagai berikut: suhu $0-200^{\circ} \mathrm{C}$ selama \pm 30 menit untuk menghilangkan air yang ada pada bahan, suhu $200-300^{\circ} \mathrm{C}$ selama \pm 60 menit merupakan proses pengarangan (bahan berubah warna menjadi hitam), suhu 300$600^{\circ} \mathrm{C}$ selama \pm 120 menit merupakan proses pengabuan (bahan berubah warna menjadi abu-abu keputihan). Abu yang dihasilkan selanjutnya didestruksi kembali dengan campuran $\mathrm{HNO}_{3}$ pekat dan aquades dengan perbandingan 1:1 sebanyak $5 \mathrm{ml}$. Abu dilarutkan sampai homogen. Larutan abu kemudian diencerkan dengan menggunakan aqua DM sampai tanda tera $25 \mathrm{ml}$ (menggunakan labu takar $25 \mathrm{ml}$ ). larutan dikocok kuat supaya semakin larut, setelah itu larutan disaring dengan kertas saring whatman no 42. Selanjutnya larutan dianalisis kandungan logam berat kadmium dengan menggunakan alat Automic Absorption Spectrophotometer (AAS).

\section{Pengamatan dan Analisis Data}

Setelah 10 MST kemudian tanaman dicabut secara perlahan-lahan dengan cara polybag dikoyak kemudian akar dicuci di dalam ember berisi air (agar akar tidak rusak). Adapun parameter yang diamati adalah $\mathrm{pH}$ tanah akhir, panjang akar $(\mathrm{cm})$, berat basah dan kering akar (g), berat basah dan kering tajuk (g), serta serapan $\mathrm{Cd}$ total (ppm). Rumus persentase berat basah (BB) dan berat kering (BK) akar dan tajuk tanaman dapat dilihat pada persamaan (1) dan (2). Rumus serapan logam berat kadmium total pada tanaman dapat dilihat pada persamaan (3).

$\%$ BB/BK Akar Tanaman $=\frac{\text { BB/BK Akar terpapar Cd-BB/BK Akar tanpa terpapar Cd }}{\text { BB/BK Akar tanpa Cd }} \times 100 \%$

$\% \mathrm{BB} / \mathrm{BK}$ Tajuk Tanaman $=\frac{\text { BB/BK Tajuk terpapar Cd-BB/BK Tajuk tanpa terpapar Cd }}{\text { BB } / \text { BK Tajuk tanpa } \mathrm{Cd}} \times 100 \%$

Serapan Logam Berat Cd Total Tanaman $=\frac{\text { Konsentrasi Cd } \mathrm{x} \text { volume larutan }}{\text { Berat sampel }}$

\section{HASIL DAN PEMBAHASAN}

\section{Kemasaman Tanah}

Data $\mathrm{pH}$ tanah awal dan akhir evaluasi tanaman dalam penelitian ini (Tabel 1). Kondisi pH tanah akhir pada perlakuan tanaman yang terpapar logam berat $\mathrm{Cd}$ berkisar 5,48-5,63 (masam-agak masam) dimana kemasaman tanah akhir mengalami perubahan sebesar $0,36-0,51$. Sedangkan pada tanaman tanpa terpapar logam berat $\mathrm{Cd}$ memiliki $\mathrm{pH}$ tanah akhir berkisar 5,41-5,94 atau mengalami perubahan sebesar $0,29-0,82$.
Hasil penelitian menunjukkan bahwa terjadi perubahan $\mathrm{pH}$ tanah awal pada penanaman enam spesies tanaman yang terpapar dan tanpa terpapar logam berat $\mathrm{Cd}$. Peningkatan $\mathrm{pH}$ yang terjadi dengan adanya pertumbuhan tanaman dapat dikaitkan dengan keberadaan mikroba dan perubahan kapasitas tukar kation.

Menurut Hardjowigeno, (2007) menyatakan bahwa tanah dengan $\mathrm{pH}$ masam didominasi oleh kation-kation masam seperti $\mathrm{Al}^{3+}$ dan $\mathrm{H}^{+}$. 
Tabel 1. Perubahan rataan $\mathrm{pH}$ pada evaluasi spesies tanaman yang terpapar $\mathrm{Cd}$ dan tanpa terpapar $\mathrm{Cd}$ selama 10 MST.

\begin{tabular}{|c|c|c|c|c|c|}
\hline \multirow[b]{2}{*}{ Tanaman } & \multirow[b]{2}{*}{$\mathrm{pH}$ awal } & \multicolumn{2}{|c|}{ Terpapar Cd } & \multicolumn{2}{|c|}{ Tanpa Terpapar Cd } \\
\hline & & $\mathrm{pH}$ akhir & Perubahan (+/-) & $\begin{array}{c}\mathrm{pH} \\
\text { akhir }\end{array}$ & Perubahan (+/-) \\
\hline T1 (akar wangi) & & $\begin{array}{c}5,53 \\
(\mathrm{AM})\end{array}$ & $+0,41$ & $\begin{array}{r}5,57 \\
(\mathrm{AM})\end{array}$ & $+0,45$ \\
\hline T2 (serai wangi) & & $\begin{array}{r}5,63 \\
(\mathrm{AM})\end{array}$ & $+0,51$ & $\begin{array}{r}5,94 \\
(\mathrm{AM})\end{array}$ & $+0,82$ \\
\hline T3 (temulawak) & & $5,48(\mathrm{M})$ & $+0,36$ & $\begin{array}{r}5,52 \\
(\mathrm{AM})\end{array}$ & $+0,40$ \\
\hline T4 (serai) & $5,12(\mathrm{M})$ & $\begin{array}{c}5,56 \\
(\mathrm{AM})\end{array}$ & $+0,44$ & $5,41(\mathrm{M})$ & $+0,29$ \\
\hline T5 (nilam) & & $\begin{array}{r}5,56 \\
(\mathrm{AM})\end{array}$ & $+0,44$ & $\begin{array}{r}5,54 \\
(\mathrm{AM})\end{array}$ & $+0,42$ \\
\hline T6 (lengkuas) & & $5,49(\mathrm{M})$ & $+0,37$ & $\begin{array}{r}5,75 \\
(\mathrm{AM}) \\
\end{array}$ & $+0,45$ \\
\hline
\end{tabular}

Keterangan :M = masam, $\mathrm{AM}$ = agak masam (Sumber : Balai Penelitian Tanah Bogor, 2009).

\section{Berat Basah dan Kering Akar Tanaman}

Data rataan berat basah dan berat kering akar pada evaluasi tanaman dalam penelitian ini disajikan pada Tabel 2. Diperoleh 3 jenis tanaman yang memiliki persentase tertinggi akibat pemberian logam berat $\mathrm{Cd}$, yaitu tanaman lengkuas, nilam, dan serai wangi.

Pemberian $\mathrm{Cd}$ juga mampu meningkatkan berat basah dan berat kering akar tanaman serai wangi masing-masing sebesar $111,73 \%$ dan $105,83 \%$ dibandingkan tanaman tanpa terpapar Cd. Begitu pula pada tanaman nilam masing-masing sebesar $155,56 \%$ dan $200 \%$, pada tanaman lengkuas masing-masing sebesar $168,60 \%$ dan $238,89 \%$ dibandingkan pada tanah tanpa terpapar logam berat $\mathrm{Cd}$. Hal ini menunjukkan bahwa logam berat kadmium diakumulasi di akar tanaman lengkuas, nilam, dan serai wangi melalui dengan mengkhelat dari rhizosfer. Hal ini sesuai dengan literatur Kaya et al. (2010) menyatakan bahwa logam Cd tergolong logam transisi, sehingga bersifat mobile di dalam tanah karena ada proses asidifikasi dari rhizosfer dan sekresi khelat oleh akar. Cd akan diserap dan dibawa melalui jalur simplas di akar dari sel menuju ke lapisan endodermal melalui protein transport di membran plasma sel-sel akar.

Immobilisasi dan penyimpanan logam berat terjadi di bagian vakuola sel akar. Logam harus dibawa menuju ke xilem secara apoplas untuk didistribusikan ke bagian daun. Setelah mencapai daun, Cd akan masuk ke dalam sel dan mengaktivasi pembentukan ligan $\mathrm{Cd}$ yang disebut fitokhelatin oleh enzim fitokhelatin sintasel (AtPCS1) di dalam sitoplasma. 
Tabel 2. Hasil rataan berat basah dan kering akar pada evaluasi tanaman yang terpapar Cd dan tanpa terpapar Cd selama 10 MST.

\begin{tabular}{lcccccc}
\hline \multirow{2}{*}{ Tanaman } & \multicolumn{3}{c}{ Berat Basah Akar $(\mathrm{g})$} & \multicolumn{3}{c}{ Berat Kering Akar $(\mathrm{g})$} \\
\cline { 2 - 6 } & $\begin{array}{c}\text { Terpapar } \\
\text { Cd }\end{array}$ & $\begin{array}{c}\text { Tanpa } \\
\text { Terpapar Cd }\end{array}$ & $\%$ & Terpapar & Tanpa & $\%$ \\
& 9,36 & 9,47 & -1.16 & 1,47 & 1,77 & -16.95 \\
T1 (akar wangi) & 25,09 & 11,85 & 111.73 & 9,88 & 4,80 & 105.83 \\
T2 (serai wangi) & 7,82 & 6,49 & 20.49 & 1,45 & 1,03 & 40.78 \\
T3 (temulawak) & 16,27 & 17,45 & -6.76 & 5,84 & 5,84 & 0.00 \\
T4 (serai) & 0,46 & 0,18 & 155.56 & 0,18 & 0,06 & 200.00 \\
T5 (nilam) & 2,31 & 0,86 & 168.60 & 0,61 & 0,18 & 238.89 \\
T6 (lengkuas) & & & & & & \\
\hline
\end{tabular}

\section{Panjang Akar Tanaman}

Data panjang akar pada evaluasi tanaman dalam penelitian ini disajikan pada Gambar 2. Hasil penelitian ini menunjukkan bahwa hanya tanaman serai wangi yang memiliki panjang akar $(75,33 \mathrm{~cm})$ yang berkembang saat terpapar logam berat kadmium dibandingkan tanaman lainnya. Sedangkan tanaman akar wangi, temulawak, serai, nilam dan lengkuas mempunyai pola pertumbuhan akar yang terhambat saat terpapar logam berat kadmium dibandingkan tanpa terpapar kadmium. Hal ini menunjukkan bahwa akar tanaman serai wangi lebih adaptif saat tercekam logam berat kadmium. Hal ini disebabkan tanaman serai wangi bersifat fitoekstraksi dimana logam berat kadmium yang terdapat di akar ditanslokasikan ke bagian tajuk tanaman sehingga pertumbuhan (panjang) akar tidak terganggu. Sedangkan akar tanaman akar wangi, temulawak, serai, nilam dan lengkuas terhambat disebabkan terjadinya kerusakan akar yang dibuktikan dengan tekstur akar lunak, kerdil, dan rambut akar terputus. Hal ini sesuai dengan literatur Ashraf et al. (2010) yang menyatakan bahwa kadar logam berat yang tinggi dalam limbah maka akan merusak dan merubah susunan sel akar. Selain itu Mardikaningtyas et al. (2016) menyatakan bahwa morfologi akar tanaman Pistia stratiotes yang ditumbuhkan di medium hidroponik masih lengkap dengan tekstur yang masih segar dan bulu akar yang masih segar. Berbeda dengan tanaman yang ditumbuhkan di medium limbah, mempunyai tekstur akar yang lunak dan rambut akar sebagian besar terputus. - Terpapar Cd $\quad$ Tanpa Terpapar Cd

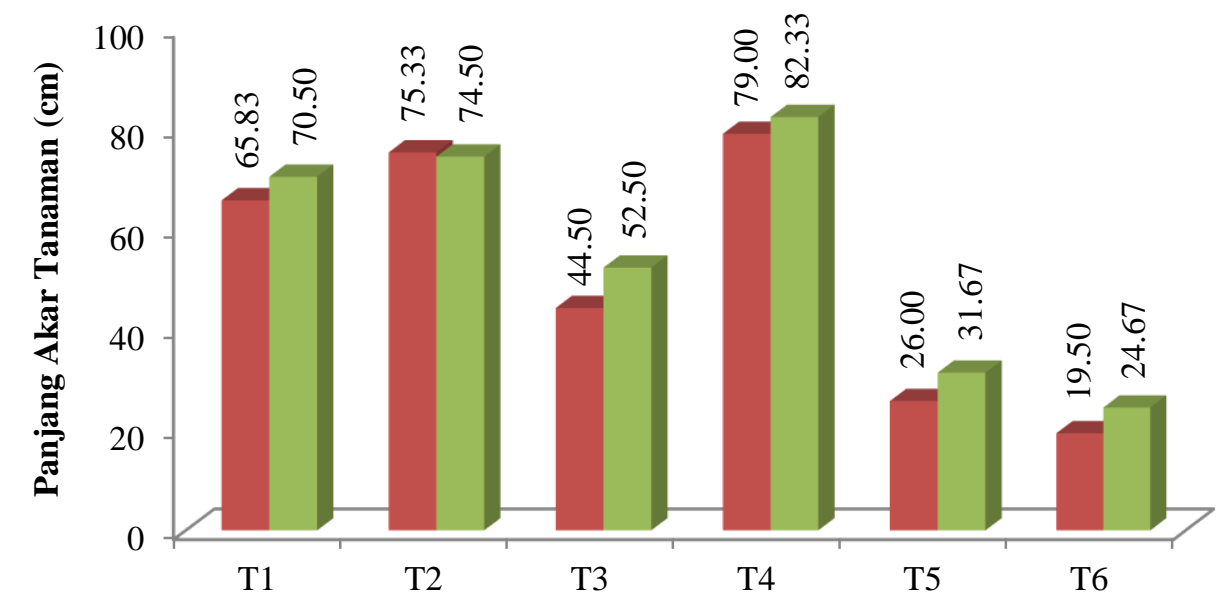

Gambar 2. Panjang akar tanaman (cm). $\mathrm{T}_{1}$ (akar wangi), $\mathrm{T}_{2}$ (serai wangi), $\mathrm{T}_{3}$ (temulawak), $\mathrm{T}_{4}$ (serai), $\mathrm{T}_{5}$ (nilam), dan $\mathrm{T}_{6}$ (lengkuas). 
Tabel 3. Rataan berat basah dan kering tajuk pada evaluasi tanaman yang terpapar Cd dan tanpa terpapar Cd selama 10 MST.

\begin{tabular}{lcccccc}
\hline \multirow{2}{*}{ Tanaman } & \multicolumn{3}{c}{ Berat Basah Tajuk (g) } & \multicolumn{3}{c}{ Berat Kering Tajuk $(\mathrm{g})$} \\
\cline { 2 - 6 } & $\begin{array}{c}\text { Terpapar } \\
\text { Cd }\end{array}$ & $\begin{array}{c}\text { Tanpa } \\
\text { Terpapar Cd }\end{array}$ & $\%$ & Terpapar & Tanpa & $\%$ \\
Cd & Terpapar Cd & \\
\hline T1 (akar wangi) & 43,30 & 50,23 & -13.80 & 15,56 & 18,61 & $-16,39$ \\
T2 (serai wangi) & 83,58 & 51,95 & 60.89 & 33,49 & 17,34 & 93,14 \\
T3 (temulawak) & 60,02 & 51,33 & 16.93 & 25,04 & 18,13 & 38,11 \\
T4 (serai) & 74,43 & 86,42 & -13.87 & 21,45 & 23,39 & $-8,29$ \\
T5 (nilam) & 8,48 & 12,37 & -31.45 & 1,22 & 2,64 & $-53,79$ \\
T6 (lengkuas) & 55,15 & 52,25 & 5.55 & 24,33 & 19,42 & 25,28 \\
\hline
\end{tabular}

\section{Berat Basah dan Kering Tajuk Tanaman}

Pemberian logam berat $\mathrm{Cd}$ pada tanaman serai wangi meningkatkan berat basah dan kering tajuk tertinggi masingmasing sebesar $60,89 \%$ dan $93,14 \%$. Hal ini menunjukkan bahwa tanaman serai wangi memiliki mekanisme kerja penyerapan logam berat kadmium yang tergolong fitoekstraksi atau fitoakumulasi. Hal ini menunjukkan bahwa terdapat pola linier antara pertumbuhan akar (berat basah dan kering) dan tajuk tanaman serai wangi. Hal ini dapat dilihat dari biomassa (berat basah dan kering tajuk) tanaman serai wangi tergolong tinggi dibandingkan tanaman lainnya. Logam berat kadmium yang terdapat di akar ditranslokasi ke bagian tajuk tanaman (batang dan daun). Hal ini sesuai dengan literatur Gosh and Singh, (2005) yang menyatakan bahwa penyerapan logam berat, tumbuhan membentuk enzim reduktase pada membran akar yang berfungsi mereduksi logam. Dari akar kemudian logam berat diangkut melalui jaringan pengangkut (xilem dan floem) ke bagian lain tumbuhan. Untuk meningkatkan efisiensi pengangkutan, logam diikat oleh molekul khelat (molekul pengikat). Selanjutnya, logam berat diakumulasikan di seluruh bagian tanaman terutama pada akar, batang, dan daun. Menurut Purakayastha and Chhonkar, (2010) bahwa tanaman yang tergolong fitoakumulasi dapat mengekstrak logam dalam konsentrasi yang besar ke dalam akar, kemudian menstranslokasikannya ke tajuk dan memproduksi biomassa tanaman dalam jumlah besar. Pemindahan logam berat dapat didaur ulang kembali dari biomassa tanaman yang telah terkontaminasi.

\section{Serapan Cd Total pada Tanaman}

Hasil penelitian ini menunjukkan persentase serapan logam berat $\mathrm{Cd}$ total pada tanaman tertinggi terdapat pada serai wangi (T2) sebesar 20,29 ppm. Hal ini menunjukkan bahwa tanaman serai wangi memiliki kemampuan yang lebih tinggi dalam fitoremediasi logam berat kadmium baik di akar, maupun tajuk (batang dan daun) dibandingkan tanaman lainnya. Hal ini sesuai dengan literatur Lin and Aarts, (2012) menyatakan bahwa penyerapan $\mathrm{Cd}$ dari tanah oleh tanaman dipengaruhi oleh total pemasukan $\mathrm{Cd}$ dalam tanah, $\mathrm{pH}$ tanah, kandungan $\mathrm{Zn}$, jenis tanaman dan kultivar. Menurut penelitian Aremu et al. (2013) menyatakan bahwa tanaman akar wangi yang terpapar logam berat kadmium selama 30 hari memiliki faktor bioakumulasi sebesar 0,2044. Penelitian Israila et al. (2015) menyatakan bahwa tanaman serai (Cymbopogon citrates) memiliki faktor translokasi dan bioakumulasi logam berat kadmium > 1 . Menurut Vineeth et al. (2014) menyatakan bahwa tanaman Curcuma longa yang terpapar logam berat $\mathrm{Cd}$, memiliki serapan $\mathrm{Cd}$ di rhizoma dan daun masing-masing sebesar $0,050 \pm 0,0026 \mathrm{mg} / \mathrm{kg}$ dan $0,046 \pm 0,003 \mathrm{mg} / \mathrm{kg}$. Penelitian Proklamasiningsih et al. (2018) menyatakan bahwa serapan $\mathrm{Cd}$ pada akar, batang dan daun tanaman nilam (Pogostemon cablin) yang terpapar logam berat cadmium 1000 ppm + 1000 ppm $\mathrm{PbNO}_{3}$ masing-masing sebesar 0,12 $\mathrm{mg} / \mathrm{kg} ; 0,07 \mathrm{mg} / \mathrm{kg}$; dan $0,03 \mathrm{mg} / \mathrm{kg}$. 


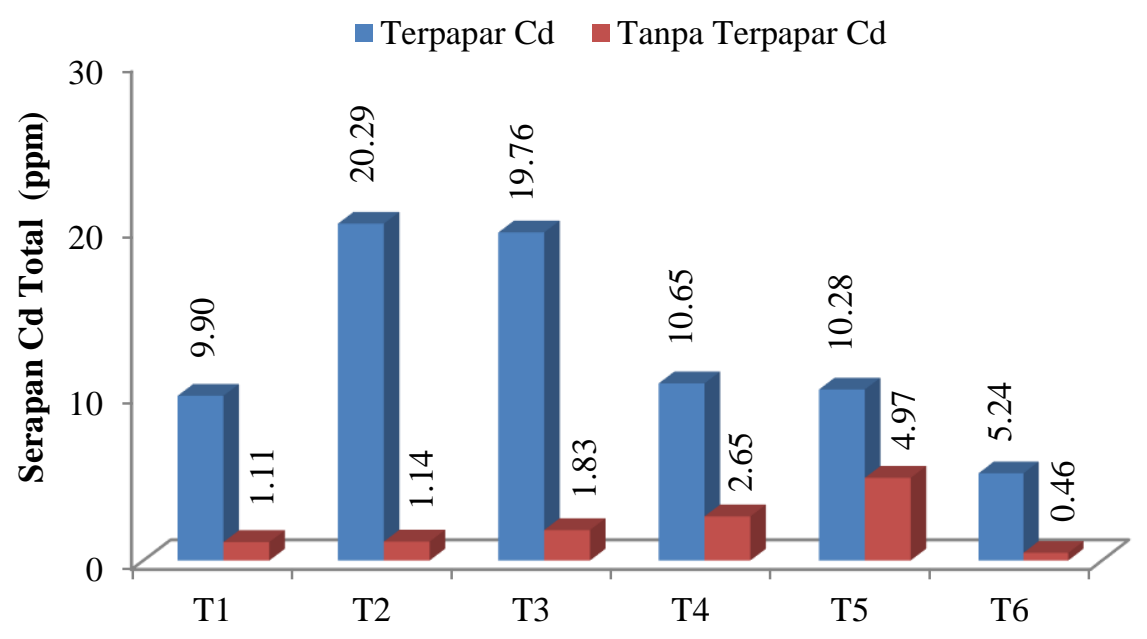

Gambar 3. Serapan Cd total pada tanaman (ppm). $\mathrm{T}_{1}$ (akar wangi), $\mathrm{T}_{2}$ (serai wangi), $\mathrm{T}_{3}$ (temulawak), $\mathrm{T}_{4}$ (serai), $\mathrm{T}_{5}$ (nilam), dan $\mathrm{T}_{6}$ (lengkuas).

Berdasarkan parameter panjang akar, berat basah akar, berat kering akar, berat basah tajuk, berat kering tajuk, dan serapan Cd total diperoleh bahwa tanaman serai wangi memberikan data pertumbuhan yang tertinggi pada tanah yang terpapar $\mathrm{Cd}$ dibandingkan spesies tanaman yang lain. Hal ini menunjukkan bahwa logam berat $\mathrm{Cd}$ dengan konsentrasi 100 ppm memberikan pengaruh yang baik bagi pertumbuhan tanaman serai wangi atau dengan perkataan lain bahwa serai wangi dapat dijadikan sebagai tanaman fitoremediasi. Menurut Zhao et al. (2003) menyatakan tanaman ideal yang dapat digunakan untuk fitoekstraksi harus memiliki biomassa yang tinggi, memiliki faktor bioakumulasi logam yang tinggi dan memiliki toleransi logam yang tinggi. Sebaliknya, spesies tanaman yang memadai untuk fitostabilisasi harus memiliki karakteristik toleransi terhadap logam tingkat tinggi, sistem akar yang berlimpah, cepat tingkat pertumbuhan dan biomassa tinggi di lapangan (Marques et al. 2009).

\section{SIMPULAN}

Tanaman serai wangi memiliki kemampuan mengakumulasi logam berat $\mathrm{Cd}$ total tertinggi sebesar 20,29 ppm, memiliki berat basah akar (111,73\%), berat kering akar
$(105,83 \%)$, panjang akar $(75,33 \mathrm{~cm})$, berat basah tajuk $(60,89 \%)$, dan berat kering tajuk $(93,14 \%)$ dibandingkan tanpa terpapar Cd. Tanaman serai wangi dapat dijadikan sebagai tanaman fitoremediasi logam berat kadmium yang memiliki mekanisme fitoekstraksi atau fitoakumulasi.

\section{UCAPAN TERIMA KASIH}

Penulis mengucapkan terima kasih kepada Kementerian Keuangan melalui LPDP dan Fakultas Pertanian Universitas Sumatera Utara yang telah mendukung penelitian ini dalam penyediaan lahan maupun alat-alat laboratorium.

\section{DAFTAR PUSTAKA}

A'yun LQ, MD Maghfoer, \& T Wardiyati. 2015. Pengaruh Panjang Tunas dan Bobot Rimpang terhadap Pertumbuhan Tanaman Temulawak (Curcuma xanthorrhiza Roxb.). Jurnal Produksi Tanaman, 3 (7): 600 - 606.

Aremu MO, AF Ogundola, \& OT Emmanuel. 2013. Phytoextraction Potential of Vetiveria zizanioides on Heavy Metals. European Scientific Journal, 9 (15): 8996. 
Ashraf M, M Ozturk, \& MSA Ahmad. 2010. Plant Adaptation and Phytoremediation. Springer. https://doi.org/10.1007/978-90-4819370-7.

Chen Y, Z Shen, \& X Li. 2004. The use of Vetiver Grass (Vetiveria zizanioides) in the Phytoremediation of Soils Contaminated with Heavy Metals. Applied Geochemistry Journal, 19 (10): 1553-1565. https://doi.org/10.1016/j.apgeochem.2 004.02.003.

Clemens S, MG Palmgren, \& U Kramer. 2002. A Long way Ahead: Understanding and Engineering Plant Metal Accumulation. Trends Plant Sci, 7 (7): 309-315.

https://doi.org/10.1016/S13601385(02)02295-1.

Ghosh M, \& SP Singh. 2005. A Review on Phytoremediation of Heavy Metals and Utilization of Its by Product. Journal Applied Ecology and Environmental Research, 3 (1): 1-18.

Hapsari RI, \& SU Lestari. 2017. Fitoremediasi Logam Berat Kadmium (Cd) pada Tanah yang Tercemar dengan Tanaman Biduri (Caloptropis gegantea) dan Rumput Gajah (Panicum maximum). Jurnal Hijau Cendekia, 2 (1): 9-14.

Hardjowigeno HS. 2007. Ilmu Tanah. Akademika Pressindo. Jakarta.

Hardyanti N, \& SS Rahayu. 2007. Fitoremediasi Phospat dengan Pemanfaatan Eceng Gondok (Eichhornia crassipes) (Studi Kasus Pada Limbah Cair Industri Kecil Laundry). Jurnal Presipitasi, 2 (1) : 2833.https://doi.org/10.14710/presipitasi. v2i1.28-33.

Israila YZ, AE Bola, GC Emmanuel, \& IS Ola. 2015. Phytoextraction of Heavy Metals by Vetivera zizanioides, Cymbopogon citrates and Helianthus annuls. American Journal of Applied Chemistry, 3 (1): $\quad 1-5$. https://doi.org/10.11648/j.ajac.201503 01.11 .

Kaya G, C Ozcan, \& M Yaman. 2010. Flame Atomic Absorption Spectrometric Determination of $\mathrm{Pb}, \mathrm{Cd}$, and $\mathrm{Cu}$ in Pinus nigra L. and Eriobotrya japonica Leaves Used as Biomonitors in Environmental Pollution. Bulletin Environmental Contamination Toxicology, 84 (2): 191-196. https://doi.org/10.1007/s00128-0099865-7.

Lin YF, \& MG Aarts. 2012. The Molecular Mechanism of Zinc and Cadmium Stress Response in Plants. Cellular and Molecular Life Sciences, 69 (19): 3187-3206.

Mardikaningtyas DA, Ibrohim, \& E Suarsini. 2016. Efektifitas Tanaman Pistia stratiotes dalam Menyerap Logam Berat Kadmium (Cd) yang Terkandung dalam Limbah Cair Pengolahan Tepung agar Ditinjau dari Akumulasi Logam di Organ Akar dan Daun. Prosiding Seminar Nasional II, Kerjasama Prodi Pendidikan Biologi FKIP dengan Pusat Studi Lingkungan dan Kependudukan (PSLK) Universitas Muhammadiyah Malang. 26 Maret 2016.

Marques APGC, AOSS Rangel, \& PML Castro. 2009. Remediation of Heavy Metal Contaminated Soils: Phytoremediation as a Potentially Promising Clean-up Technology. Crit. Rev. Environ. Sci. Technol, 39 (8): 622-654.

https://doi.org/10.1080/106433807017 98272.

McGrath SP, J Zhao, \& E Lombi. 2002. Phytoremediation of Metals, Metalloids, and Radionuclides. Adv Agron, 75 : 1-56. https://doi.org/10.1016/S00652113(02)75002-5.

Nopriani LS. 2011.Teknik Uji Cepat untuk Identifikasi Pencemaran Logam Berat Tanah di Lahan Apel Batu. Disertasi 
Doktor pada Fakultas Pertanian. Universitas Brawijaya.

Proklamasiningsih E, I Budisantoso, \& Kamsinah. 2018. Cadmium (Cd) Absorption and Phenol Content in Pogostemon Exposed to Heavy Metals. The Journal of Tropical Life Science, 8 (1): 6-10. https://doi: 10.11594/jtls.08.01.02.

Purakayastha TJ, \& PK Chhonkar. 2010. Phytoremediation of Heavy Metal Contaminated Soils. Berlin Heidelberg: Springer.

Sumiartha K, N Kohdrata, \& NS Antara. 2012. Modul Pelatihan Budidaya dan Pasca Panen Tanaman Sereh (Cymbopogon citratus (DC.) Stapf.). Pusat Studi Ketahanan Pangan, Universitas Udayana.

Tsao DT. 2003. Phytoremediation. Advance in Biochemical Engineering Biotechnology. Berlin Heidelberg: Springer.

Vineeth D, C Venkateshwar, \& SA Unnisa. 2014. Treatment of Curcuma longa
(Turmeric) Contaminated with Heavy Metals. World Journal of Pharmaceutical Research, 3 (9): 460468.

Zhang X, B Gao, \& H Xi. 2014. Effect of Cadmium on Growth, Photosynthesis, Mineral Nutrition and Metal Accumulation of Bana Grass and Vetiver Grass. Ecotoxicology and Environmental Safety Journal, 106: 102-108.

https://doi.org/10.1016/j.ecoenv.2014. 04.025 .

Zhao FJ, E Lombi, \& SP McGrath. 2003. Assessing the Potential for Zinc and Cadmium Phytoremediation with the Hyperaccumulator Thlaspi caerulescens. Plant and Soil, 249 (1): 37-43.

https://doi.org/10.1023/A:1022530217 289.

Zoidis E, K Fegeros, G Zervas, PF Surai, \& AC Pappas. 2010. Cadmium Toxicity and The Antioxidant System. New York : Nova Science Pub Inc. 